\title{
The Impact of Hyperoxia on the Neonatal and Adult Developing Dendritic Cell
}

\author{
CYNTHIA MASALUNGA, HENRY J. ROZYCKI, AND ELSIE S. MAINALI
}

Department of Pediatrics, Virginia Commonwealth University Health System, Richmond, Virginia 23298

\begin{abstract}
Oxygen is essential therapy for neonates with acute respiratory failure, including those with infections. However, high oxygen levels may be counterproductive for overcoming infections because hyperoxia may kill cells, including dendritic cells that are essential to the emergence of the pulmonary immune system and pivotal in mounting immune responses to infections. We studied the impact of hyperoxia on developing dendritic cells from neonatal cord blood and adult blood monocytes, comparing viability, development of maturation, and endocytic function. Our data suggest that cord blood-derived dendritic cells may be more resistant to hyperoxicinduced cell death than adult blood-derived cells. Moreover, the surviving cells in either group are those that maintain an immature phenotype. This may impair their ability to perform optimal immune function. (Pediatr Res 62: 78-82, 2007)
\end{abstract}

$\mathbf{I}^{\mathrm{n}}$ nfection is one of the most important causes of mortality and morbidity among newborns with acute respiratory failure (1). Inhaled oxygen is a vital therapy for these infants, despite the potential risks of hyperoxia to the lung, including affecting the DNA integrity of type II pneumocytes (2), and normal immune responses in the lungs $(3,4)$. Hyperoxia alters the pulmonary tissue immune response by up-regulating proinflammatory cytokines and inducing neutrophil infiltration in the alveolar spaces (5). It also increases alveolar macrophage apoptosis (4), further weakening the immune response (3). We investigated whether hyperoxia might likewise interfere with the development of DC, immune cells that are more important for presenting antigen to $\mathrm{T}$ cells than are macrophages.

While the majority of term infants exposed to hyperoxia recover, occasionally with some residual morbidity, adults under similar conditions do not survive beyond a few days $(6,7)$. To investigate whether this differential response to oxygen is reflected in DC function and viability, we compared the hyperoxic effect on developing DC from neonates versus adults.

\section{MATERIALS AND METHODS}

Cell culture and hyperoxia. Pulmonary dendritic cells, which are exposed to the highest levels of oxygen, are predominantly of myeloid origin (8) and resemble monocyte-derived DC from cord or adult peripheral blood (9). After institutional board review and informed consent, cord blood from normal term pregnancies was collected into sterile collection bags and processed within

Received August 22, 2006; accepted February 27, 2007.

Correspondence: Elsie S. Mainali, M.D., Ph.D., Department of Pediatrics, VCUHS, 401 North 12th Street, Room 6-500, Richmond, VA 23298; e-mail: emainali@vcu.edu

Flow cytometry work was supported in part by National Institutes of Health Grant P30 CA16059.
24 h. Some cord blood was supplied by the St. Louis Cord Blood Bank and solely used for determining the optimal duration of hyperoxia exposure. Although the blood from preterm cord blood would be more reflective of the clinical setting underlying this study, limited volume and, therefore, smaller cell numbers made it impractical. Adult blood was collected by venipuncture from healthy volunteers. The dendritic progenitor cells were extracted from mononuclear cells as described previously (10). Briefly, the mononuclear cells were separated from red cells by sedimentation with a solution of hydroxyethyl starch followed by density centrifugation over Histopaque-1077 (Sigma Chemical Co., St. Louis, MO). The cells adhering after 1-h incubation (monocyte lineage cells) were cultured at $37^{\circ} \mathrm{C}$ in RPMI 1640 and $10 \%$ FCS enriched with $800 \mathrm{U} / \mathrm{mL}$ rhGM-CSF and $80 \mathrm{ng} / \mathrm{mL}$ rhIL-4. (R \& D Systems, Minneapolis, MN). To induce maturation of the DC, 20-ng/mL lipopolysaccharide (LPS, Sigma Chemical Co.) was added to the culture at d 5.

Hyperoxic conditions were created by incubating half of the cell cultures in an oxygen-saturated chamber (Billups-Rothenberg, Del Mar, CA), as previously described (11), with a gas mixture of $95 \% \mathrm{O}_{2}$ and $5 \% \mathrm{CO}_{2}$ for 2 , 5 , or 7 consecutive days. This oxygen level is chosen to produce the maximal exposure and is comparable to that exposed to the sickest patients. Two, five, and seven days of exposure to hyperoxia had been predetermined experimentally, via a doses-response study, as optimal for detecting differences in viability of the cells from both cord and adult blood (data not shown). Control cells were incubated in $21 \% \mathrm{O}_{2}$ and $5 \% \mathrm{CO}_{2}$. To account for any confounding effects of incubation before hyperoxia, all cells were incubated for $1 \mathrm{~h}$ at $37^{\circ} \mathrm{C}, 21 \% \mathrm{O}_{2}$ and $5 \% \mathrm{CO}_{2}$, before being exposed to $95 \%$ or $21 \%$ oxygen The oxygen was thereafter reintroduced every $2 \mathrm{~d}$ to maintain the stated level (11).

At the end of 2,5, and $7 \mathrm{~d}$, the cells were enumerated and viability was determined by negative staining with trypan blue. The ratio of remaining cells after exposure to $95 \%$ oxygen to remaining cells following $21 \% \mathrm{O}_{2}$ was expressed as the "hyperoxia index."

Phenotypic marker analysis. At the end of a 7-d incubation period, the cells were incubated with mouse anti-human fluorescent MAb against CD1a (immatured-DC marker), CD83 (matured-DC marker), HLA-DP/Q/R (HLAII), or with isotype-matched antibodies (all from BD PharMingen, San Diego, CA) for $60 \mathrm{~min}$ at $4{ }^{\circ} \mathrm{C}$. Flow cytometry data were acquired using an Epics-XL-MCL flow cytometer (Beckman Coulter, Inc., Fullerton, CA). A subpopulation was defined for its high concentration of cells that shared similar forward as well as side scatter and tendency to express DC markers. All data were analyzed for marker quantity (percentage of cells that expressed DC markers within the subpopulation) and for marker intensity (MFI, mean fluorescence intensity: the number of markers expressed per cell) using Cytomics RXP software (Beckman Coulter).

Measurement of endocytic activity. The ability of cells to take up and catalyze the self-quenched green bodipy dye conjugate of BSA (DQ-BSA) (Molecular Probes, Eugene, OR) was used to measure endocytosis, a function of immature DC (12). Cells were incubated with DQ-BSA (10 $\mu \mathrm{g} / \mathrm{mL}$ in RPMI 1640 containing $10 \%$ fetal bovine serum) for $1 \mathrm{~h}$ at $37^{\circ} \mathrm{C}$ (controls were incubated on ice), washed twice with PBS containing $0.1 \% \mathrm{NaN}_{3}$ and $0.1 \%$ BSA (Sigma Chemical Co.), and endocytic activity was measured by flow cytometry.

Cell viability analysis. The changes in cell viability were quantified by determining the amount of bound FITC-conjugated Annexin-V (AV-FITC) (BD PharMingen) and propidium iodide (PI). Per manufacturer's recommendations, $5 \mu \mathrm{L}$ AV-FITC was incubated with $10^{5}$ cells for $15 \mathrm{~min}$ at room temperature in the dark followed by $5 \mu \mathrm{L}$ of $50 \mu \mathrm{g} / \mathrm{mL}$ PI for another $15 \mathrm{~min}$, then the whole promptly analyzed by flow cytometry. Cells in apoptosis (annexin-V positive, PI negative), apoptosis-necrosis (annexin-V positive and

Abbreviations: AB, adult blood; CB, cord blood; DC, dendritic cells; ROS, reactive oxygen species 
PI positive), and necrotic cells (annexin-V negative, PI positive) were then quantified using flow cytometry.

Quantification of ROS. Cells cultured for $7 \mathrm{~d}$ were exposed to either $21 \%$ or $95 \% \mathrm{O}_{2}$ for 1,4 , or $24 \mathrm{~h}$. The ROS reagent (Molecular Probes) reacts specifically with hydrogen peroxide $\left(\mathrm{H}_{2} \mathrm{O}_{2}\right)$, which converts $2^{\prime}, 7^{\prime}$ dichlorodihydrofluorescein diacetate into $2^{\prime}, 7^{\prime}$-dichlorofluorescein (13). It was freshly reconstituted with anhydrous DMSO and added to the cells at a concentration of $1 \mu \mathrm{g} / \mathrm{mL}$ of media during the last $15 \mathrm{~min}$ of $\mathrm{O}_{2}$ exposure (14). The cells were washed twice with PBS and ROS were immediately quantified by determining the mean fluorescence intensity from each treatment group by flow cytometry.

Statistical methods. All experiments in this study were conducted three or more times. The marker patterns within each experiment for Figure 1 were reproducible but the magnitude of responses between experiments was variable, prompting us to illustrate the results of one individual experiment accompanied by a table summarizing the first phenotypic marker experiments (Fig. 1). To minimize individual variation, some of the data were represented as the ratio of the treated group to the control group for marker quantity and intensity of positive cells within the DC subpopulation (Table 1, Figs. 2 and 3). Mean values of the ratios and their SD were calculated for each variable. Data were analyzed using $t$ test with Bonferroni correction for multiple comparisons where appropriate.

\section{RESULTS}

Hyperoxia reduced the number of mature DC. We first determined the effect of hyperoxia on the expression of CD1a and CD83 (Fig. 1). Double-negative (CD1 $\left.{ }^{-} / \mathrm{CD}^{-} 3^{-}\right)$cells derived from both $\mathrm{CB}$ and $\mathrm{AB}$ increased after $5 \mathrm{~d}$ of hyperoxia, as noted by the increased density in the lower left portion of the dot plots. However, the proportion of CB-derived cells that expressed CD1a and the intensity of that expression, were not affected by hyperoxic exposure, indicating a resistance to change of the number of CD1a CB-derived cells. In ABderived cells, $5 \mathrm{~d}$ of hyperoxia significantly decreased both the number and the intensity of CD1a expression ( $p \geq 0.001$ and 0.004 , respectively), indicating that early in maturation, $\mathrm{AB}$ derived DC are susceptible to hyperoxic damage. The direction and magnitude of change in the percentage of $\mathrm{CD} 1 \mathrm{a}$ CB-derived DC relative to that of CD1a AB-derived DC due to hyperoxia was remarkable: under hyperoxic conditions, the percentage of CB-derived CD1a DC remained the same as was found under normoxic conditions ( $23 \%$ versus $26 \%$ ), but the percentage of $\mathrm{AB}$-derived $\mathrm{CD} 1 \mathrm{a} \mathrm{DC}$ decreased (from $59 \%$ to $16 \%$ ), indicating a resistance of young $\mathrm{CB}$-derived $\mathrm{DC}$ to hyperoxia compared with young $\mathrm{AB}$-derived $\mathrm{DC}$.

Concomitantly, both the CB-derived and AB-derived DC expressing the later maturity marker, $\mathrm{CD} 83$, decreased to $<5 \%$. Altogether, these data imply that, although the less mature CB-derived DC are more resistant than AB-derived DC to hyperoxic injury, both $\mathrm{CB}$-derived mature $\mathrm{DC}$, as well as $\mathrm{AB}$ derived mature $\mathrm{DC}$, are vulnerable to hyperoxic damage.

Two days of hyperoxia diminished marker intensity of mature CB-derived DC more than AB-derived DC. To study the effects of hyperoxia on the maturation process, we compared the $\mathrm{CB}$ - and $\mathrm{AB}$-derived $\mathrm{DC}$ ratios of the hyperoxic to

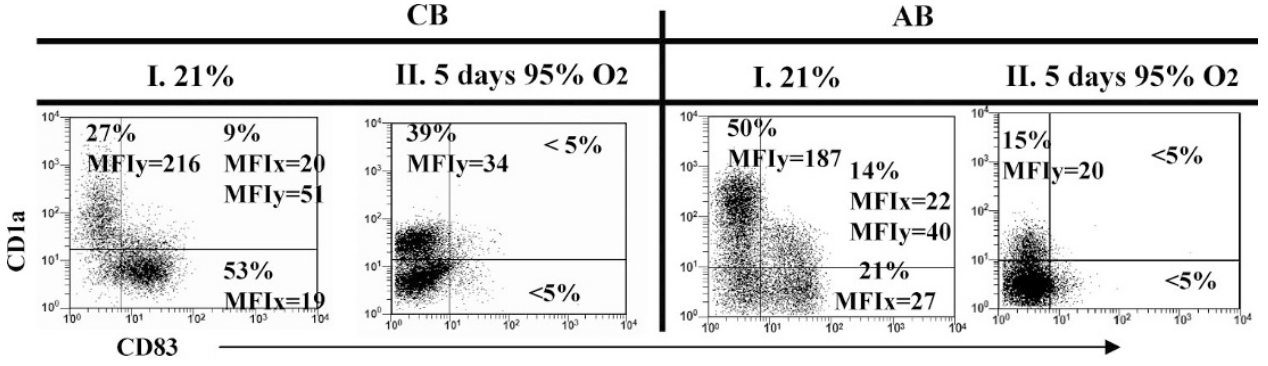

\begin{tabular}{|l|l|c|c|c|c|c|c|}
\hline \multicolumn{2}{|l|}{$\begin{array}{l}\text { Surface cell } \\
\text { markers }\end{array}$} & \multicolumn{3}{|c|}{ CB with Oxygen } & \multicolumn{3}{c|}{ AB with Oxygen } \\
\cline { 2 - 8 } & I. 21\% & II. 95\% & $p^{a}$ & I. 21\% & II. 95\% & $p^{a}$ \\
\hline \multirow{2}{*}{1. CD1a } & a. $\%$ & $23 \pm 8$ & $26 \pm 8$ & 0.16 & $59 \pm 18$ & $16 \pm 6$ & 0.001 \\
\cline { 2 - 8 } & b. MFI & $105 \pm 63$ & $39 \pm 6$ & 0.04 & $154 \pm 73$ & $27 \pm 13$ & 0.004 \\
\hline \multirow{2}{*}{2. CD83 } & a. $\%$ & $34 \pm 22$ & $4 \pm 1.2$ & 0.01 & $37 \pm 6$ & $4.5 \pm 1$ & 0.001 \\
\cline { 2 - 8 } & b. MFI & $57 \pm 5$ & $35 \pm 11$ & 0.11 & $27 \pm 0.4$ & $13 \pm 4$ & 0.002 \\
\hline
\end{tabular}

Figure 1. Hyperoxia (5 d 95\% oxygen exposure) reduced the number of mature (CD83) DC in both $\mathrm{CB}$ and $\mathrm{AB}$ cells but immature (CD1a) CB-DC less than in

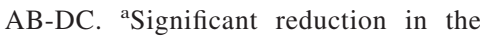
number of CD83-positive cells incubated on $21 \%$ vs $95 \%$ oxygen with $p<0.0253$ (Bonferroni correction for two comparisons). $n=3$ or more individuals per group treatment.

Table 1. Comparison of CB-DC vs AB-DC after 2 (I) and 5 (II) days of continuous hyperoxia

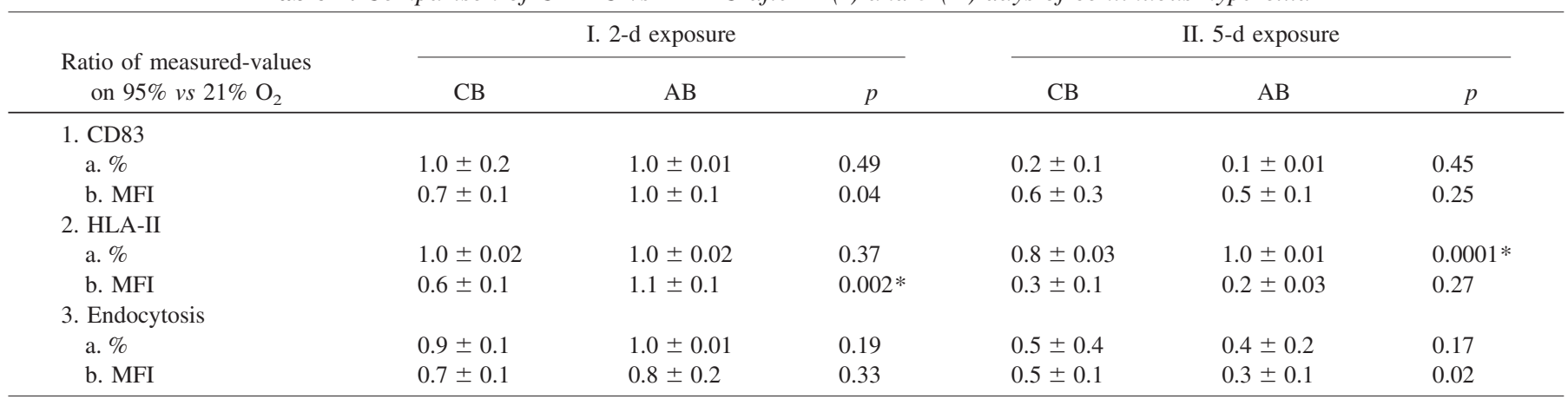

$* p<0.017$ for CB-DC vs AB-DC after Bonferroni correction. $n=3-5$ individuals per group treatment. 


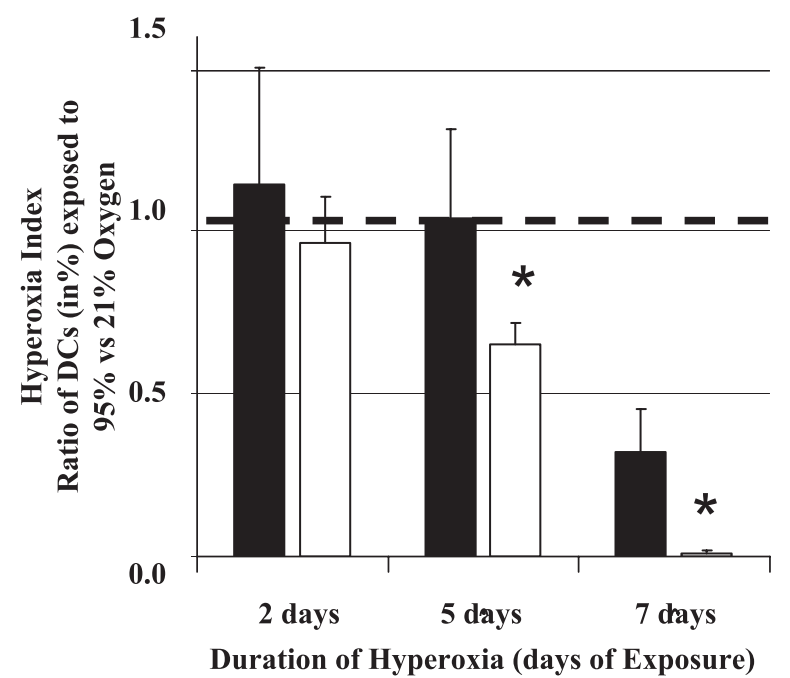

Figure 2. Prolonged hyperoxia decreased the number of cells less signifi-

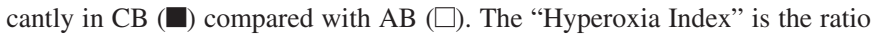
of remaining cells after exposure to $95 \% \mathrm{O}_{2}$ over remaining cells following $21 \% \mathrm{O}_{2}$. The horizontal broken line represents the hyperoxia index of $21 \% \mathrm{O}_{2}$ treated cells from each individual, which is equal to $1 . n=5-9$ in each group; $* p<0.05 . t$ test was used to analyze the difference between $95 \%$ vs $21 \% \mathrm{O}_{2}$ exposures from the same group of cells; $p=0.04$ for $5 \mathrm{~d}$ and $p=0.02$ for $7 \mathrm{~d}$ hyperoxia group, respectively.

normoxic marker quantity and intensity (Table 1). After $2 \mathrm{~d}$ of hyperoxia (column I), there was no significant difference in the relative number of DC expressing CD83 or HLA-II in both $\mathrm{CB}$ - and $\mathrm{AB}$-derived $\mathrm{DC}$ in the hyperoxic groups compared with the normoxic group (rows: 1a and 2a). The ratio of the intensity of expression of both markers was lowered in CBderived $\mathrm{DC}$ compared with $\mathrm{AB}$-derived $\mathrm{DC}$, although the effect is modest, and after Bonferroni correction, only those of AB-derived DC were significantly lowered (row 1b: $p=0.04$ for CD83 and 2b: $p=0.002$ for HLA-II).

After $5 \mathrm{~d}$ of exposure, the quantity and intensity of CD83mature $\mathrm{DC}$ from either $\mathrm{CB}$ or $\mathrm{AB}$ were both reduced. The difference in the HLA-II positive proportion of cells at $\mathrm{d} 5$ between CB-derived and AB-derived DC, while statistically highly significant, is of quite modest degree (Table 1). We postulate this to be due to the effect on the corresponding ration of the much more dramatic reduction in intensity of the $\mathrm{AB}$-derived than $\mathrm{CB}$-derived cells going from 2 to $5 \mathrm{~d}$ of hyperoxia (Table 1). Moreover, these findings may indicate that longer exposure indiscriminately depressed the quantity and intensity of DC expressing maturation marker CD83 and HLA-II in both CB- and AB-DC.

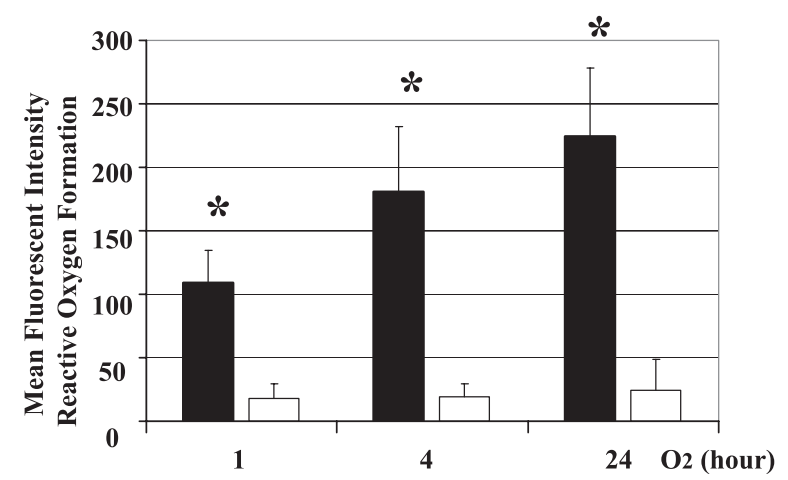

Figure 4. Hyperoxia caused higher ROS formation in CB-DC (ם) than AB-DC ( $\square$ ). The formation of intracellular ROS was measured by FACS quantification of 5-(and-6)-chloromethyl-2',7'-dichlorodihydrofluorescein diacetate, acetyl ester (CM-H2DCFDA). Data represents mean $\pm \mathrm{SD} .{ }^{*} p<$ 0.05 for $\mathrm{CB}-\mathrm{DC}$ vs $\mathrm{AB}-\mathrm{DC}$.

Hyperoxia affected endocytic activity. The ability of DC to capture antigen (endocytosis) is an important characteristic of immature DC, as this function declines with DC maturation (15). Neither a 2- nor 5-d exposure to $\mathrm{O}_{2}$ alters the endocytic activity of either $\mathrm{CB}$ or AB-DC (Table 1 , column I, rows $3 \mathrm{a}$ and $3 \mathrm{~b}$ ), suggesting that the hyperoxia did not alter the function of DC.

Hyperoxia decreased the number of viable $A B$ cells more rapidly than $\boldsymbol{C B}$ cells. To assess the impact of hyperoxia on cells' viability, we compared the ratio of cells at the end of a 7 - $\mathrm{d}$ culture between the hyperoxic $(2,5$, or $7 \mathrm{~d}$-exposure) versus normoxic groups (Fig. 2). Continuous hyperoxia for $5 \mathrm{~d}$ or more significantly decreased the number of $\mathrm{AB}$ cells $(\mathrm{CB}$ cells: $p=0.25$; $\mathrm{AB}$ cells: $p=0.02$ ), while $\mathrm{CB}$ cells were affected only after $7 \mathrm{~d}$ (CB cells: $p=0.004$; AB cells: $p=0.003$ ).

Hyperoxia caused necrosis and apoptosis in AB cells earlier than $\boldsymbol{C B}$ cells. We further compared the course of hyperoxic injury that leads to cell death by analyzing the percentage of necrotic, necrotic-apoptotic, or apoptotic cells after continuous hyperoxic exposure for 2 and $5 \mathrm{~d}$ (Fig. 3). After as little as $2 \mathrm{~d}$ of hyperoxia, the percentage of necrosed $\mathrm{AB}$ cells increased more than 3-fold, approximately double that of the CB cells ( $p=0.03$; Fig. 3, left panel first column). This difference disappeared when the cells were exposed for $5 \mathrm{~d}$ (Fig. 3, left panel; second column: both necrotic $\mathrm{CB}$ and $\mathrm{AB}$ cells increased 10 -fold over the normoxic groups). The proportion also holds true for the necrotic-apoptotic cells (Fig. 3 , middle panel). There was no difference in the degree of apoptotic cells from $\mathrm{CB}$ or $\mathrm{AB}$ cells, exposed either for 2 or $5 \mathrm{~d}$ (Fig. 3, right panel).
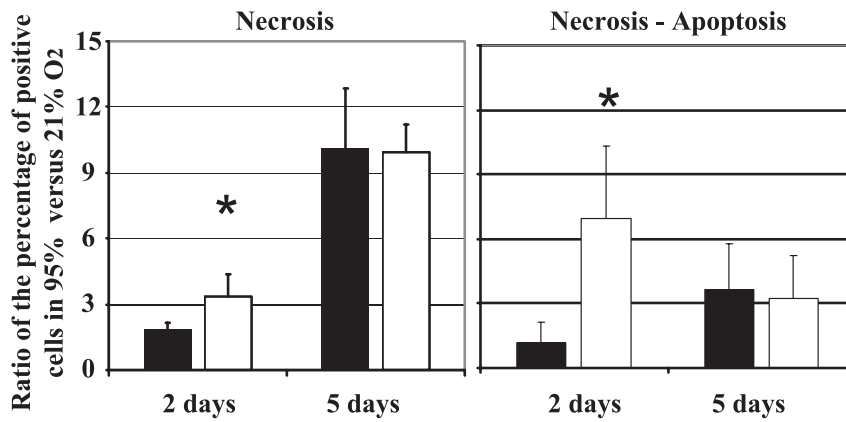

Apoptosis

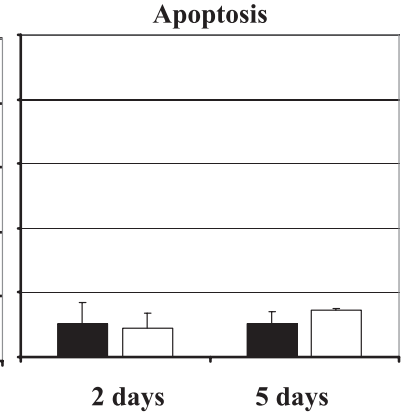

Figure 3. Hyperoxia induced cell death more gradually in $\mathrm{CB}$ - than $\mathrm{AB}-\mathrm{DC}$. The cells derived from $\mathrm{CB}(\square)$ or $\mathrm{AB}(\square)$ exposed to either $2 \mathrm{~d}$ and $5 \mathrm{~d}$ of $21 \%$ or $95 \% \mathrm{O}_{2}$ were assessed at the end of the $7 \mathrm{~d}$ culture for necrosis and apoptosis. In $2 \mathrm{~d}, \mathrm{AB}-\mathrm{DC}$ showed significant necrosis $(p=0.03)$ and necrosis-apoptosis $(p=0.02)$, where $p<$ 0.05. $t$ test (with Bonferroni correction) was used to assess the significance of the difference between $\mathrm{CB}$ vs $\mathrm{AB}$. Data represents mean \pm $\mathrm{SD}$ of six individual treatment groups. 
Hyperoxia produced higher ROS levels in CB than in $A B$ cells. To investigate the dichotomy of the response to hyperoxic injury in $\mathrm{CB}$ versus $\mathrm{AB}$ cells, we measured the level of ROS at varying durations of oxygen exposure (Fig. 4). To provide more accurate interpretation of the impact of hyperoxia on the production of ROS and rapid decline of viable cells, only the first 24-h measurement was analyzed. In CB cells, ROS increased directly with increasing exposure to hyperoxia and the amount of intracellular ROS was significantly higher in $\mathrm{CB}$ than $\mathrm{AB}$-derived cells.

\section{DISCUSSION}

Many cell types demonstrate an increased susceptibility to hyperoxic injury in more mature cells $(7,16)$. Our study extends this to dendritic cells. There is a definite predilection to hyperoxic injury by more mature dendritic cells either within the cell lineage (Fig. 1: more CD83 positive cells were reduced than $\mathrm{CD}$ 1a-positive cells in both $\mathrm{CB}$ and $\mathrm{AB}$ cells) or within different chronological ages (Fig. 1: more CD1a- and CD83-positive cells significantly reduced in AB- than CB$D C$; Fig. 2: higher reduction in cell number in $A B$ than $C B$ cells). The consistent pattern of this effect supports the conclusion that immaturity confers some protection against hyperoxic injury. Specifically, our study also showed that the length of hyperoxia determined the gravity of the negative effect on both matured CB- and AB-DC (Table 1), and the induction of apoptosis-necrosis in the developing $\mathrm{CB}$ and $\mathrm{AB}$ cells (Fig. 3), similar to the reduction in cell viability observed when other forms of oxidative stress, such as hydrogen peroxide, have been used $(17,18)$.

Our results support that of others that showed hyperoxia induced cell death through apoptotic $(19,20)$, nonapoptotic (21), or both pathways (22). This is in contrast to our previous study where dexamethasone preferentially induced apoptosis and much less necrosis, in the immature dendritic cells (23). $\mathrm{CB}$ cells were more resistant to hyperoxia than $\mathrm{AB}$ cells (Fig. 2 and 3) in the present study, despite a higher level of reactive oxygen species in CB cells (Fig. 4). Additionally, the CBderived cells showed a small but significant effect of hyperoxia on HLA-II expression (Table 1).

This paradox of increased oxidative stress from hyperoxia but less effect on immature DC or cells from cord-bloodderived cells may be explained by several previous observations. Adult cells have been shown to have lesser amounts or activity of antioxidative enzymes $(24,25)$. Adults also produce higher amounts of monocyte chemotactic protein-1 after hyperoxic exposure, which can amplify the production of inflammatory cytokines (26) that may result in cell death. In addition, there is a relative maturational difference in lung nuclear factor (NF)- $\kappa \mathrm{B}$ activation (27), a gradual switching of mitochondrial phosphorylation from glycolytic to oxidative metabolism $(28,29)$ and higher level of oxidative phosphorylation (30), resulting in higher amplification of oxygen toxicity in adult cells. Individually or in combination, these findings could explain why the adult or more mature cells appeared more susceptible to the damaging effects of hyperoxia in this study. The relative predominance of anti-inflammatory cytokines such as IL-10 in the newborn compared with adult $(10,31,32)$ may also contribute to a protective mechanism toward neonate cells against hyperoxia. We acknowledge that further work needs to clarify any effect of DMSO, the diluent used in stabilizing the dye in quantifying the oxygen reactive species, on the membrane permeability (33) of CB- versus AB-DC.

Despite their resistance toward hyperoxia, neonatal DC were more readily altered by hyperoxic exposure. For example, our study showed that within $2 \mathrm{~d}$ of hyperoxia, the number of necrotic cells was significantly higher in AB- than CB-DC, but that the CB-DC showed a significant lowering of maturation markers' expression intensity per cell (Table 1), suggesting that, in the remaining viable CB-DC, maturation was impeded. Five-day hyperoxia exposure caused the number of remaining viable cells capable of endocytic capacity to be reduced by half in both $\mathrm{CB}$ - and AB-DC, most probably via actin-dysfunction (34). However, the CB-DC capable of endocytic activity showed significantly higher ability than AB-DC to endocytose, supporting the cell marker findings that the remaining viable CB-DC were immature. There are potentially interesting implications of these findings. Immature DC activate regulatory $\mathrm{T}$ cells, promoting tolerance (35-37). Tolerance is vital in preventing premature rejection of the fetus by facilitating the suppressive effect on the maternal immune system $(38,39)$. On the other hand, tolerance increases the risk that pathogens might evade the weakened protective immunity $(36,37,40)$. It may be worth investigating whether immature neonatal DC, which are more resistant to hyperoxia, are then less able to help the immune system mount a response against invading pathogens. Baleeiro et al. (3) described the impairment of innate immunity upon exposure to sublethal hyperoxia in the adult animal. Given our current findings, investigating less mature hosts could yield significant results.

While results from our study are consistent and intriguing, several limitations and questions need to be addressed. Hyperoxia would most affect pulmonary DC and, although monocyte-derived DC strongly resemble pulmonary DC $(8,9)$, there is some evidence that the local microenvironment can affect terminal differentiation (41). Only one high concentration of oxygen was used so it is not clear whether, for example, there is a different threshold for oxygen effects in the $\mathrm{CB}$ - versus $\mathrm{AB}$-derived cells. We did not further characterize the cells that became CD1a and CD83 negative after $5 \mathrm{~d}$ in hyperoxia.

In summary, our findings demonstrate that although CB-DC are more resistant to hyperoxic-induced death than $\mathrm{AB}-\mathrm{DC}$, the surviving CB-DC are immature and dysfunctional. The survival of immature and dysfunctional DC may interfere with development of adaptive immunity in those infants with acute respiratory failure who are exposed to prolonged hyperoxia. This finding may provoke a need to reexamine the development of induced adaptive immunity through vaccination of infants exposed to prolonged hyperoxia.

Acknowledgments. The authors thank Cord Blood Bank, St. Louis University, for the supply of cord blood, and Dr. Dawn L. Thiselton for editing and critical reading of the manuscript. 


\section{REFERENCES}

1. O’Neill JM, Schutze GE, Heulitt MJ, Simpson PM, Taylor BJ 2001 Nosocomial infections during extracorporeal membrane oxygenation. Intensive Care Med 27:1247-1253

2. Barker GF, Manzo ND, Cotich KL, Shone RK, Waxman AB 2006 DNA damage induced by hyperoxia: quantitation and correlation with lung injury. Am J Respir Cell Mol Biol 35:277-288

3. Baleeiro CE, Wilcoxen SE, Morris SB, Standiford TJ, Paine R 3rd 2003 Sublethal hyperoxia impairs pulmonary innate immunity. J Immunol 171:955-963

4. Tateda K, Deng JC, Moore TA, Newstead MW, Paine R 3rd, Kobayashi N, Yamaguchi K, Standiford TJ 2003 Hyperoxia mediates acute lung injury and increased lethality in murine Legionella pneumonia: the role of apoptosis. J Immunol 170:4209-4216

5. Sinclair SE, Altemeier WA, Matute-Bello G, Chi EY 2004 Augmented lung injury due to interaction between hyperoxia and mechanical ventilation. Crit Care Med 32:2496-2501

6. Soloway HB, Castillo Y, Martin AMJr 1968 Adult hyaline membrane disease: relationship to oxygen therapy. Ann Surg 168:937-945

7. Frank L, Bucher JR, Roberts RJ 1978 Oxygen toxicity in neonatal and adult animals of various species. J Appl Physiol 45:699-704

8. Masten BJ, Olson GK, Tarleton CA, Rund C, Schuyler M, Mehran R, Archibeque T, Lipscomb MF 2006 Characterization of myeloid and plasmacytoid dendritic cells in human lung. J Immunol 177:7784-7793

9. Cochand L, Isler P, Songeon F, Nicod LP 1999 Human lung dendritic cells have an immature phenotype with efficient mannose receptors. Am J Respir Cell Mol Biol 21:547-554

10. Mainali ES, Kikuchi T, Tew JG 2005 Dexamethasone inhibits maturation and alters function of monocyte-derived dendritic cells from cord blood. Pediatr Res 58:125131

11. Rozycki HJ, Eischeid AC, Huff TF 2004 Effect of hyperoxia on interleukin-8 expression in premature versus term rabbit lung explants. Exp Lung Res 30:285-296

12. Jones LJ, Upson RH, Haugland RP, Panchuk-Voloshina N, Zhou M, Haugland RP 1997 Quenched BODIPY dye-labeled casein substrates for the assay of protease activity by direct fluorescence measurement. Anal Biochem 251:144-152

13. Bass DA, Parce JW, Dechatelet LR, Szejda P, Seeds MC, Thomas M 1983 Flow cytometric studies of oxidative product formation by neutrophils: a graded response to membrane stimulation. J Immunol 130:1910-1917

14. Vowells SJ, Sekhsaria S, Malech HL, Shalit M, Fleisher TA 1995 Flow cytometric analysis of the granulocyte respiratory burst: a comparison study of fluorescent probes. J Immunol Methods 178:89-97

15. Banchereau J, Briere F, Caux C, Davoust J, Lebecque S, Liu YJ, Pulendran B, Palucka K 2000 Immunobiology of dendritic cells. Annu Rev Immunol 18:767-811

16. Bucher JR, Roberts RJ 1981 The development of the newborn rat lung in hyperoxia: a dose-response study of lung growth, maturation, and changes in antioxidant enzyme activities. Pediatr Res 15:999-1008

17. Aderem A, Ulevitch RJ 2000 Toll-like receptors in the induction of the innate immune response. Nature 406:782-787

18. Verhasselt V, Goldman M, Willems F 1998 Oxidative stress up-regulates IL-8 and TNF-alpha synthesis by human dendritic cells. Eur J Immunol 28:3886-3890

19. Dieperink HI, Blackwell TS, Prince LS 2006 Hyperoxia and apoptosis in developing mouse lung mesenchyme. Pediatr Res 59:185-190

20. De Paepe ME, Mao Q, Chao Y, Powell JL, Rubin LP, Sharma S 2005 Hyperoxiainduced apoptosis and Fas/FasL expression in lung epithelial cells. Am J Physiol Lung Cell Mol Physiol 289:L647-L659

21. O'Reilly MA, Staversky RJ, Watkins RH, Reed CK, Mesy Jensen KL, Finkelstein JN, Keng PC 2001 The cyclin-dependent kinase inhibitor p21 protects the lung from oxidative stress. Am J Respir Cell Mol Biol 24:703-710
22. McGrath-Morrow SA, Stahl J 2001 Apoptosis in neonatal murine lung exposed to hyperoxia. Am J Respir Cell Mol Biol 25:150-155

23. Mainali ES, Tew JG 2004 Dexamethasone selectively inhibits differentiation of cord blood stem cell derived-dendritic cell (DC) precursors into immature DCs. Cell Immunol 232:127-136

24. Amicarelli F, Di Ilio C, Masciocco L, Bonfigli A, Zarivi O, D'Andrea MR, Di Giulio C, Miranda M 1997 Aging and detoxifying enzymes responses to hypoxic or hyperoxic treatment. Mech Ageing Dev 97:215-226

25. Keeney SE, Cress SE, Brown SE, Bidani A 1992 The effect of hyperoxic exposure on antioxidant enzyme activities of alveolar type II cells in neonatal and adult rats. Pediatr Res 31:441-444

26. Reale M, Di Giulio C, Cacchio M, Barbacane RC, Grilli A, Felaco M, Bianchi G, Di Gioacchino M, Conti P 2003 Oxygen supply modulates MCP-1 release in monocytes from young and aged rats: decrease of MCP-1 transcription and translation is age-related. Mol Cell Biochem 248:1-6

27. Yang G, Abate A, George AG, Weng YH, Dennery PA 2004 Maturational differences in lung NF-kappaB activation and their role in tolerance to hyperoxia. J Clin Invest 114:669-678

28. Schagger H, Noack H, Halangk W, Brandt U, von Jagow G 1995 Cytochrome-c oxidase in developing rat heart. Enzymic properties and amino-terminal sequences suggest identity of the fetal heart and the adult liver isoform. Eur J Biochem 230:235-241

29. Schonfeld P, Schild L, Bohnensack R 1996 Expression of the ADP/ATP carrier and expansion of the mitochondrial (ATP + ADP) pool contribute to postnatal maturation of the rat heart. Eur J Biochem 241:895-900

30. Frank L 1991 Developmental aspects of experimental pulmonary oxygen toxicity Free Radic Biol Med 11:463-494

31. Gasparoni A, Ciardelli L, Avanzini A, Castellazzi AM, Carini R, Rondini G, Chirico G 2003 Age-related changes in intracellular TH1/TH2 cytokine production, immunoproliferative $\mathrm{T}$ lymphocyte response and natural killer cell activity in newborns, children and adults. Biol Neonate 84:297-303

32. Rainsford E, Reen DJ 2002 Interleukin 10, produced in abundance by human newborn $\mathrm{T}$ cells, may be the regulator of increased tolerance associated with cord blood stem cell transplantation. Br J Haematol 116:702-709

33. Notman R, Noro M, O'Malley B, Anwar J 2006 Molecular basis for dimethylsulfoxide (DMSO) action on lipid membranes. J Am Chem Soc 128:13982-13983

34. O'Reilly PJ, Hickman-Davis JM, Davis IC, Matalon S 2003 Hyperoxia impairs antibacterial function of macrophages through effects on actin. Am J Respir Cell Mol Biol 28:443-450

35. Ghiringhelli F, Puig PE, Roux S, Parcellier A, Schmitt E, Solary E, Kroemer G, Martin F, Chauffert B, Zitvogel L 2005 Tumor cells convert immature myeloid dendritic cells into TGF-beta-secreting cells inducing $\mathrm{CD} 4+\mathrm{CD} 25+$ regulatory $\mathrm{T}$ cell proliferation. J Exp Med 202:919-929

36. Lutz MB, Schuler G 2002 Immature, semi-mature and fully mature dendritic cells which signals induce tolerance or immunity? Trends Immunol 23:445-449

37. Steinman RM, Hawiger D, Nussenzweig MC 2003 Tolerogenic dendritic cells. Annu Rev Immunol 21:685-711

38. Takahata $\mathrm{Y}$, Nomura A, Takada $\mathrm{H}$, Ohga S, Furuno K, Hikino S, Nakayama $\mathrm{H}$, Sakaguchi S, Hara T 2004 CD25+CD4 + T cells in human cord blood: an immunoregulatory subset with naive phenotype and specific expression of forkhead box $\mathrm{p} 3$ (Foxp3) gene. Exp Hematol 32:622-629

39. Cupedo T, Nagasawa M, Weijer K, Blom B, Spits H 2005 Development and activation of regulatory $\mathrm{T}$ cells in the human fetus. Eur J Immunol 35:383-390

40. Steinman RM, Nussenzweig MC 2002 Avoiding horror autotoxicus: the importance of dendritic cells in peripheral $\mathrm{T}$ cell tolerance. Proc Natl Acad Sci U S A 99:351-358

41. Gogolak P, Rethi B, Szatmari I, Lanyi A, Dezso B, Nagy L, Rajnavolgyi E 2007 Differentiation of CD1a- and CD1a+ monocyte-derived dendritic cells is biased by lipid environment and PPARgamma. Blood 109:643-652 